\title{
STRONG LIBRARIES, STRONG SOCIETIES
}

\author{
Bibliotecas fuertes, sociedades fuertes
}

Sinikka Sipilä

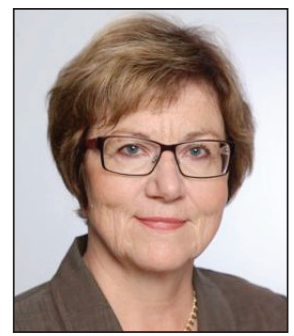

Sinikka Sipilä is president of IFLA, 2013-2015, and has been secretary general of the FLA (Finnish Library Association) since 1997. Ms. Sipilä completed her master's degree in social sciences at the University of Tampere, with specialization in library and information sciences. She was a member of the Standing Committee of Management of Library Associations Section (MLAS) in 2003-2011 and served as the chair of MLAS from 2007 to 2009. She was also the co-chair of the National Committee of the IFLA World Library and Information Congress 2012 in Helsinki. She has been an advisor to NorthSouth-South Programme involving universities in Finland, South Africa, Namibia, Tanzania, and Senegal. She was a library expert on libraries and sustainable development in Finland, The Philippines, and Ghana. She served as a librarian and project coordinator at a library of the educational centre for South African refugees Somafco in Tanzania in 1991-92 http://somafcotrust.org.za/about-the-trust-2/timeline http://orcid.org/0000-0003-0881-9398

Finnish Library Association Runeberginkatu 15 a 6.00100 Helsinki, Finland Tel.: +358-400-659363 sinikka.sipila@fla.fi

\section{Abstract}

Libraries have an impact on society by fostering equal opportunities to lifelong learning and education, research and innovation, culture and recreation for all. Strong libraries are those that have adequate capacity to meet the information needs of their user communities. Strong societies consist of informed citizens who actively participate in the life of their community and society. Crucial for strong libraries and strong societies is the democratic ideal -freedom of access to information for all.

\section{Keywords}

Public libraries; Social services; Social inclusion; Social insertion; Marginal groups; Marginalized; Special groups; Digital divide; Refugees; Migrants; Civil rights; Literacy; Third world; International Federation of Library Associations and Institutions; IFLA.

\section{Resumen}

Las bibliotecas tienen un impacto en la sociedad mediante el fomento de la igualdad de oportunidades para el aprendizaje permanente y la educación, la investigación y la innovación, la cultura y la recreación para todos. Las bibliotecas fuertes son las que tienen la capacidad adecuada para satisfacer las necesidades de información de sus usuarios. Las sociedades sólidas están integradas por ciudadanos informados que participan activamente en la vida de su comunidad y la sociedad. Crucial para las bibliotecas fuertes y las sociedades fuertes es el ideal democrático -libertad de acceso a la información para todos.

\section{Palabras clave}

Bibliotecas públicas; Servicios sociales; Inserción social; Inclusión social; Grupos marginales; Marginados; Colectivos especiales; Brecha digital; Refugiados; Emigrantes; Derechos civiles; Alfabetización; Tercer mundo; International Federation of Library Associations and Institutions; IFLA.

\section{Sipilä, Sinikka (2015). “Strong libraries, strong societies”. El profesional de la información, v. 24, n. 2, pp. 95-101.}

\section{http://dx.doi.org/10.3145/epi.2015.mar.02}

\section{Note}

This text is an adaptation of the invited paper the author presented as a keynote speaker at the past Bobcatsss conference, Brno, Czech Republic, 28-30 January 2015.

http://www.bobcatsss2015.com/wp 


\section{Introduction}

My topic today is Strong libraries, strong societies which is my IFLA (International Federation of Library Associations and Institutions) presidential theme. Each IFLA president chooses a theme that best describes her or his goals during the presidency. I chose the theme because I firmly believe libraries exert a critical impact on society by fostering equal opportunities and providing equitable access to lifelong learning and education, research and innovation, culture and recreation for all. In so doing, libraries can contribute to building stronger communities and societies. Libraries can promote and support citizens' active participation in the life of their communities and help their users to also participate in the development of activities at their libraries. This is becoming more and more important. Libraries are no longer simply delivering their services, but planning and developing them together with the people who are using them. This is the way libraries keep and earn their legitimacy. Participation is the keyword.

\section{Background of the theme}

IFLA is actively working on projects and initiatives relating to libraries and development, in particular the impact libraries have on development. This also inspired me when I planned my theme.

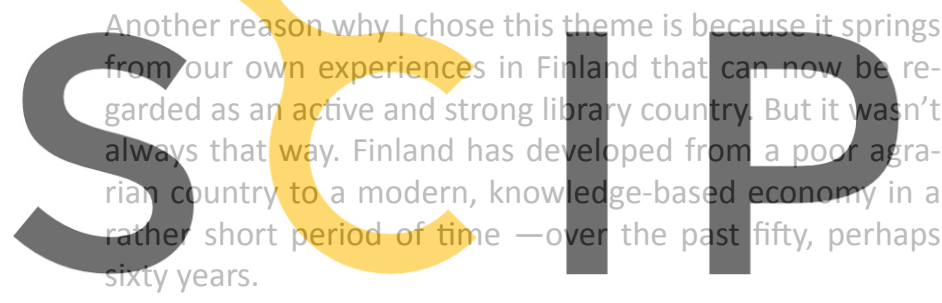

We differ from most developed western.countries in the

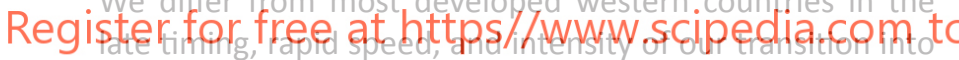
our present $21^{\text {st }}$ century industrial state.

The Finnish government has promoted an effective education system and free access to information through an extensive library network as part of the welfare state policy. According to our constitution, it is a basic right for citizens to have freedom of access to information. Finland has one of the first library acts in Europe from 1928. Libraries are seen as crucial actors in promoting this kind of access and they are included also in what is called the Government Platform, which is the highest political framework for action and public policy in Finland.

I believe it is also because of such enlightened government policies that today about $80 \%$ of Finns are regular library users. Books, reading, and libraries are highly valued in Finland. Both public and research libraries are open and free of charge to all. In a National Finnish Library customer survey conducted in 2010 , over $70 \%$ of the 13,000 respondents stated that libraries had improved their quality of life. The Ministry of Education and Culture conducted in 2011 the first study of the benefits of libraries. It showed that $71 \%$ use libraries for fiction, $67 \%$ for non-fiction, and $58 \%$ for self-education in their leisure time. The impact of libraries on literacy has been strong and the results can be seen in the good results of Finnish students in the PISA
(Programme for International Student Assessment) organized by the $O E C D$.

Education and literacy have been the pathways that have allowed individuals to rise in their societies. That was clearly expressed in the texts three Finnish library associations gathered from library users some years ago. We received over 600 essays of how libraries had changed people's lives. There were many touching stories including those from elderly people who had lived in remote areas during childhood and adolescence, yet their municipality had a library, usually a small library at the local school, and often it was the only public service available. They found the library to be a source for knowledge, recreation, comfort, socializing, and an eye-opening gateway to the world, which led to new possibilities and opportunities in their lives.

One story was from an author who has published several fiction and non-fiction books and plays. He described how he started to use the library and found there a treasuretrove of fiction and poetry that inspired him to write. The library was his university. Without it and its dedicated staff he would not have achieved what he has and is today. And, particularly heart-warming, he especially thanked a branch librarian who had been most helpful and supportive; in fact this librarian had made him believe in his talents and encouraged him to become an author.

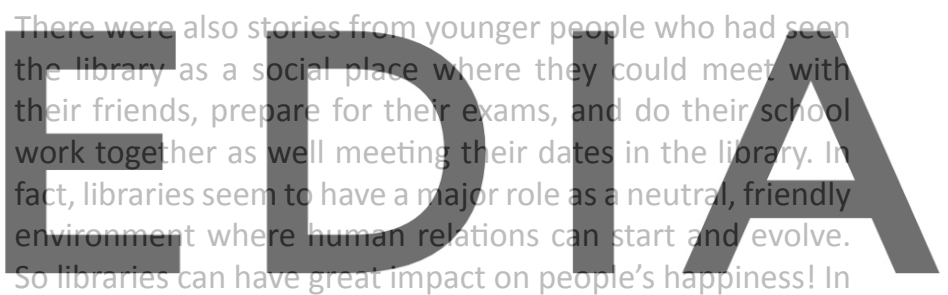

many of the stories, the atmosphere of libraries was descri-

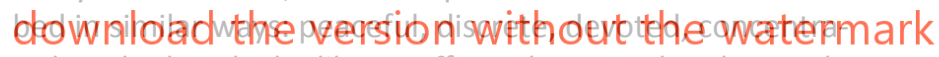
ted, and relaxed. The library offers a haven to lonely people and to some who need to rest. It allows people to be with themselves among other people and participate in activities and events offered by the library.

My experiences during my term of presidency have strengthened my belief in the impact of libraries on society. I have visited many countries such as Singapore, Russia, Mexico, Namibia, and Tanzania and many more and have seen the importance of access to information for economic, cultural, and social development of each country.

In Namibia there was a conference in 2013 dedicated to my theme in the African context. The presentations showed clearly how relevant and timely my theme is for many of the libraries and librarians in Africa. Many of the discussions that were held on this theme generated helpful recommendations for libraries and librarians to play a more active role in society by turning libraries into an integral part of society and playing this role more actively.

I was happy to have the chance to visit Tanzania again, where some years ago I was working in a library of an educational center for South African refugees. That early experience of the library and information environment in Africa influenced me also when I chose my presidential theme. In Tanzania I experienced the power of knowledge to people living in 
exile, far away from their home country. The library was the heart of the refugee center. It provided that community with a variety of materials from their home country, such as literature, newspapers, films, music, and cultural events to ease their homesickness and to prepare them for repatriation when that time eventually came.

In Tanzania I also had an opportunity to speak to a large group of students, at a library school in Bagamoyo, and discuss with them their views and concerns on the future of libraries. Through a North-South-South programme between universities in Finland and African countries, I have been informed of important issues to students and professors in the field.

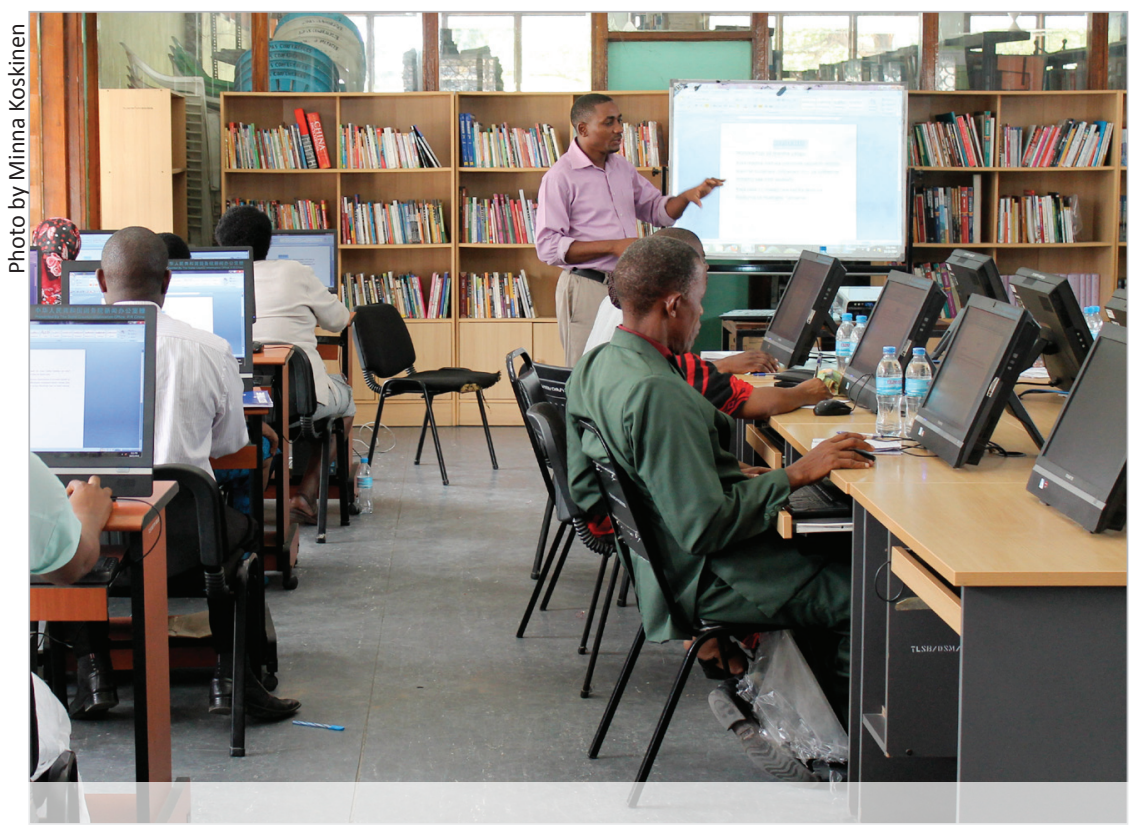

I have also learned from my experiences in other projects related to libraries in Africa and Asia that libraries are a great place for delivering environmental materials for citizens. I was involved in a project to raise awareness of the potential that libraries can offer in guiding people on how they can take better care of their own en-

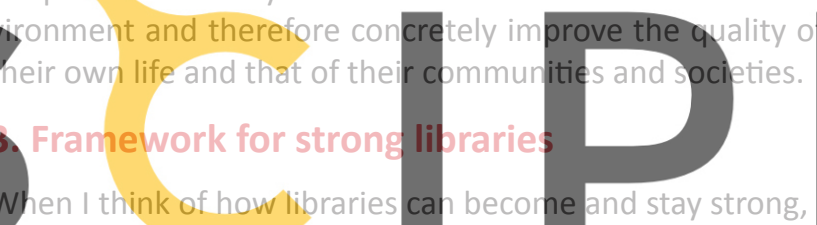

mework. By that I mean governments must recognize the the evenings and weekends when people have more time to use the library, but when there is not enough staff to work for more hours. This arrangement requires the installation of

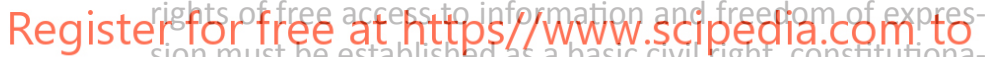

Ily and through legislation. Library legislation, in fact, must provide strong support for the development of comprenensive library and information services.

It is important that there are national library policies with strategic documents outlining this path. National recommendations or standards are also needed to promote consistency in service delivery.

It follows then that with such recognition and policy support from governments, libraries can legitimately request sustainable funding for the key services they provide to the community. Not just for the provision of improved physical infrastructure and collections, but also the availability of library education to train more professional staff.

If we wish to secure as many working places in libraries as possible, in spite of the economic downturn and difficulties in national and local budgets, then it is crucial to clearly communicate the importance of qualified staff to good library and information services and in that way to the concept of strong libraries. Even though we have some libraries in Finland and in some other countries open for extended hours without staff being present, that does not mean libraries no longer need trained staff. This new concept allows libraries to offer their facilities and collections to users for longer opening hours in
Libraries can legitimately request sustainable funding for the key services that they provide to the community. Not just for the provision of improved physical infrastructure and collections, but also the availability of library education to train more professional staff

\section{How to define a strong library?}

So how do we define strong libraries? Perhaps their strength is defined by their mission. Professor R. David Lankes (2011), of Syracuse University, USA, has suggested the core mission of libraries, public or otherwise, is creating a nation of informed and active citizens, and the job of the library is to fulfill the needs of the community members, not simply to house materials.

From my perspective, to accomplish this goal the libraries must be seen by their user communities as welcoming safe places, with adequate space and catalogs, staffed by competent and helpful personnel, and providing access to up- 


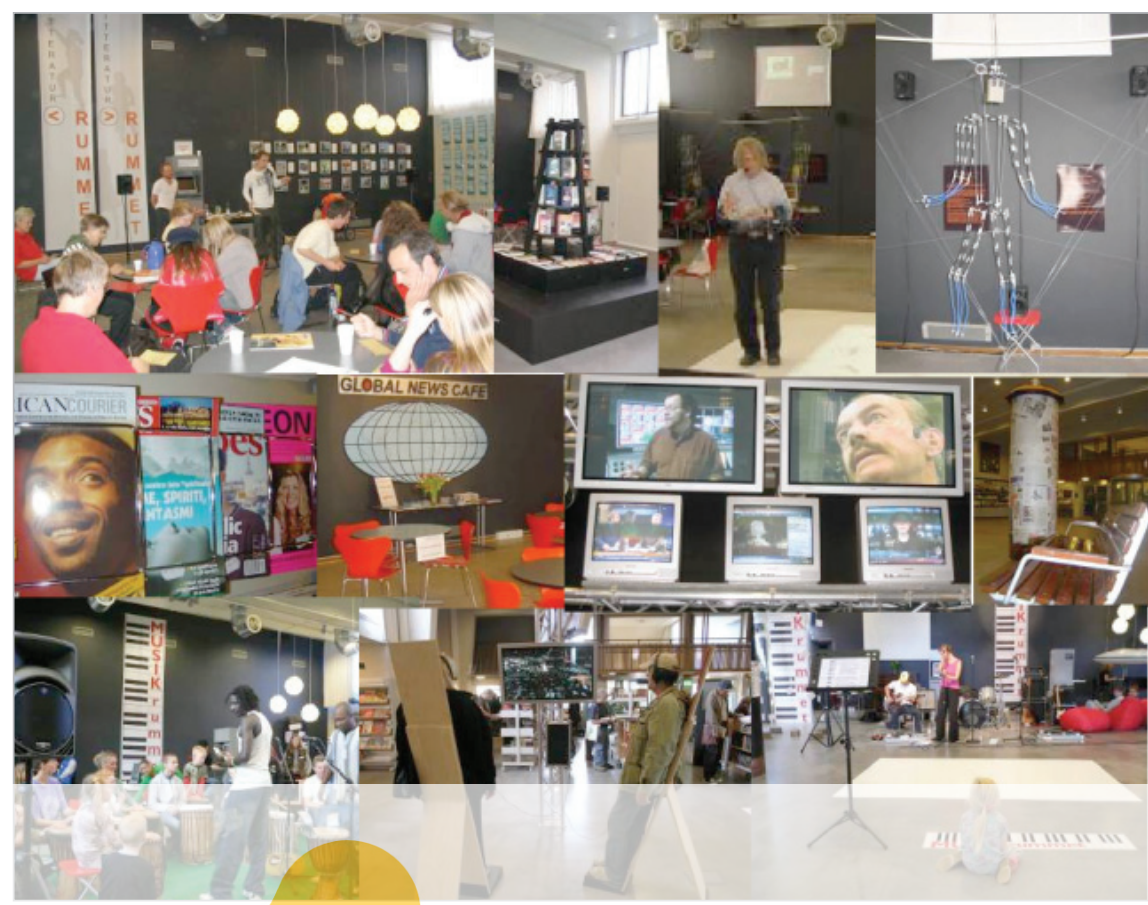

New times, new library activities (Schulz, 2014)

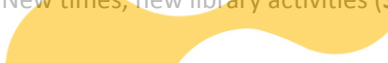

to-date resources relevant to their needs, including digital content.

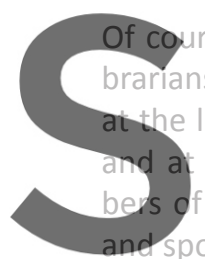

rse this all can't be left to That burden is too grea ocal and national levels by t the international level by
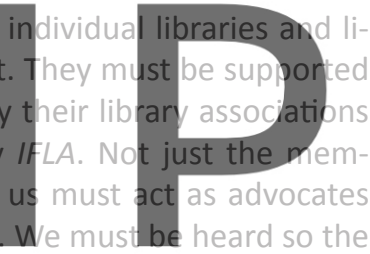

decision-makers and politicians and other relevant stakehol-

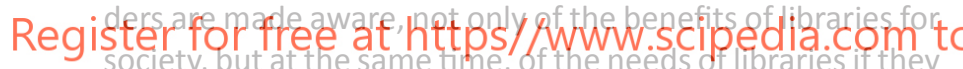
are to fulfill their mandates, including fostering community development.

We must be heard so that the decisionmakers and politicians and other relevant stakeholders are made aware, not only of the benefits of libraries for society, but at the same time, of the needs of libraries if they are to fulfill their mandates, including fostering community development

It is here that we need to explore impact research and studies to demonstrate how libraries can have an impact on and benefit the communities and societies they serve. If we want to reassure the funders of the important role libraries play we need to base our arguments on facts and hard evidence. There is plenty of research available on this issue. It is our duty to highlight these facts so they can be of benefit to all libraries. Libraries must be more vocal in publicizing the role they can play, not only in the cultural context, but also in the economic, educational, and social lives of the communities they serve.

Furthermore, it would be useful to emphasize to decision makers, perhaps especially to politicians, that the economic return for investing in libraries is excellent. Surveys have consistently shown that for every euro spent on libraries about four euros are returned in economic benefits to the communities they serve. It is only through such advocacy that libraries can hope to secure adequate funding even during harsh economic times.

\section{What is a strong society like?}

If that is what strong libraries look like, then what is the profile of a strong society? It stands to reason that strong societies consist of informed citizens who actively participate in the life and activities of their community. So, participation lies at the core of my theme. Strong libraries that can meet the information, recreational, cultural, educational, and social needs of their users can promote and support participation
and involvement in a democratic society. Active citizenship
forms the basis for a democratic society and therefore in-
formation and knowledge are the modern tools of citizens-
hip-universal availability through libraries is essential.
Strong societies are open, free, and equal, giving their citizens the possibility to use all their knowledge, abilities, and

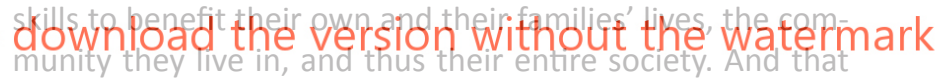
lies at the heart of all socio-economic development.

\section{Participation and libraries}

Libraries are enablers and equalizers that make it possible for all people to live a rich life and participate to their full potential in the activities of their communities.

I link participation strongly with civil society. According to a Finnish definition made by Aaro Harju (2003), a civil society is characterized by citizens' spontaneity and activeness, participation and doing, public utility and autonomy, voluntariness and optionality, laymanship and professionalism, flexibility and independence, communality and locality, ethics and solidarity. In a civil society, citizens organize activities and services for themselves as well as for others out of their own hopes and premises.

Harju also states that the spontaneity and activeness of citizens stem first and foremost from the willingness to participate and act. People are motivated when they have an interest in some subject matter. The willingness to participate, to take part and to gather experiences, adds substance to people's lives. Spontaneous activity acts as a good counterbalance to work and brings variety to an individual's life. Through participation, the person can make new friends 


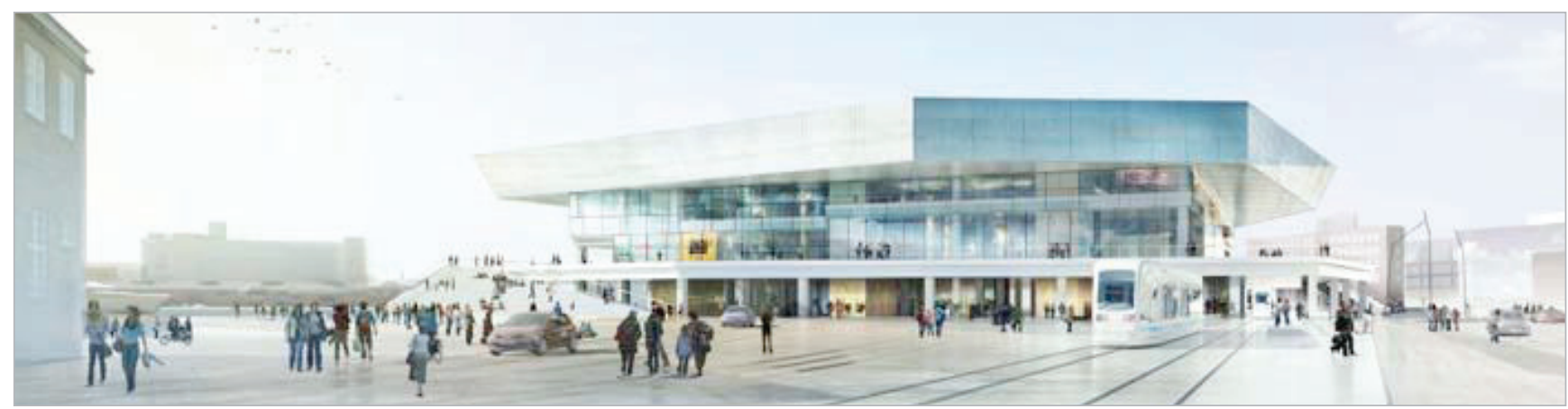

As a part of the project Urban Mediaspace, the city of Århus has build the new library Dokk1, on Århus harbour by the mouth of the river

and break the circle of loneliness. The desire to learn for oneself, but also help others, encourages many people to be active and participate in the activities of civil society.

Participation offers the opportunity and ability to exert an influence. A civil society provides numerous ways in which an individual can make a difference. The possibility to have an influence represents an important dimension of citizens' spontaneous activities within the contexts of civil society.

Surveys have consistently shown that for every euro spent on libraries about four euros are returned in economic benefits

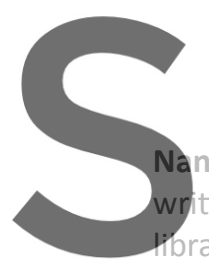
to the communities

cy Kranich (2001) from Rutgers

ten about libraries and a

ries serve to prepare citizen
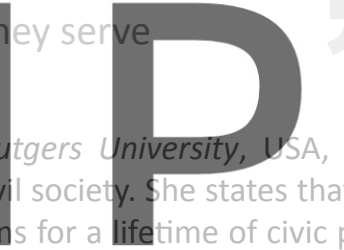

ticipation, they also encourage the development of a

Register for frey grovide the information and the opportuni-

common concerns. As community forums, they encourage active citizenship that renew and invigorate communities. When people are better informed, they are more likely to participate in policy discussions in which they can freely communicate their ideas and concerns. Most importantly, citizens need civic spaces where they can speak freely, share similar interests and concerns, and pursue what they believe is in their interest. Librarians can teach the public how to identify and evaluate information that is essential to making decisions that affect the way they live, work, learn, and govern themselves. Libraries also provide the real and virtual spaces for members of the community to exchange ideas -ideas fundamental to democratic participation and civil society. This is exactly what I mean by "Strong libraries, strong societies".

The Internet environment represents a new kind of participatory culture that is also affecting the functions of libraries. Libraries are part of the communities they serve and changes in those communities will be felt sooner or later in the functioning of libraries. Libraries have been the forerunners of networking and the large use of information technology by library patrons. Libraries are one of the most active users of social media in municipalities, and market their events and exhibitions in the social media as it reaches out to groups that usually are not reached through library communication channels or through advertisement in newspapers. The traditional task of libraries has not changed. Thanks to advanced net services, library and information services are just more effective and diverse.

Libraries are public spaces. Some libraries have linked the participatory culture of civil society to library planning to find best solutions to meet the needs of their users. I would like to give examples from Denmark, UK, and Finland of this type of civic participation in library planning.

\section{1. Århus, Denmark}

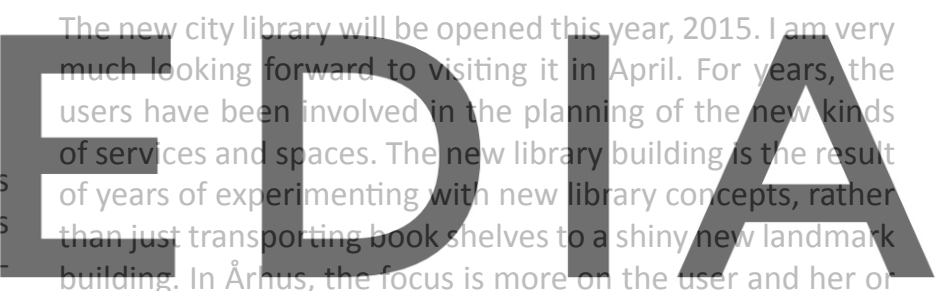

his interests and needs. Everybody's opinion is important.

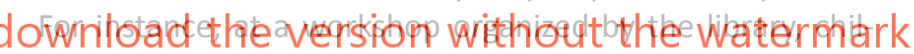

dren were allowed to use their imagination and give free rein to their ideas. They came back with ideas like bookshelves that can be climbed up, a bouncy castle, a ball pool, animals in a garden and fruit trees with swings on them. It became clear that children might find it boring to look at all those bookshelves in the library. Children need more space to move around.

Children came back with ideas like bookshelves that can be climbed up, a bouncy castle, a ball pool, animals in a garden and fruit trees with swings on them

The comments coming from users in World Café2 discussions, in experimental labs, or workshops have provided hints to the architects for their work to help them empathize with the world of children, the handicapped, and other user groups. The library's partners, i.e. educational institutions, clubs and organizations which use the library, were also able to give their input, wishes, and ideas for the interior design. In Århus, the library is seen also as a center for innovation. Certain events are in the pipeline, especially those related to the "maker-culture", which means the "do-it-yourself" culture of 
our electronic age. The focus at these events will be on what can be done with technological junk, for example, how an old iPad can be used for other functions. According to Knud Schulz, the manager of the library in Århus, the libraries of the future will be concerned with people, not just media. Schulz has stated that they, the librarians, considered the library as a place, as a space, and as a relation. First: the library as a place within the city, as a landmark and as a catalyst of urban development. Second: the library as a space for social interaction, as an important hub of the public domain, and as an experience. Third: the library as a relation, with other cultural institutions and creative entrepreneurs. The new building was designed to facilitate these new roles for the library.

\subsection{Idea Stores, and Birmingham Central Library, UK}

There are also libraries that have had active discussions with their users while they have planned new library buildings or services. Idea Stores are new types of libraries that have been developed in London during the last decade; they are more than just a library or a place for learning. As well as library services, they offer a wide range of adult learning courses and an impressive program of activities and events. The library staff spent two years in discussions with different user groups before starting to plan the first Idea Store.

In Birmingham, the new main library was opened in 2013 and there too, the citizens were involved in the planning

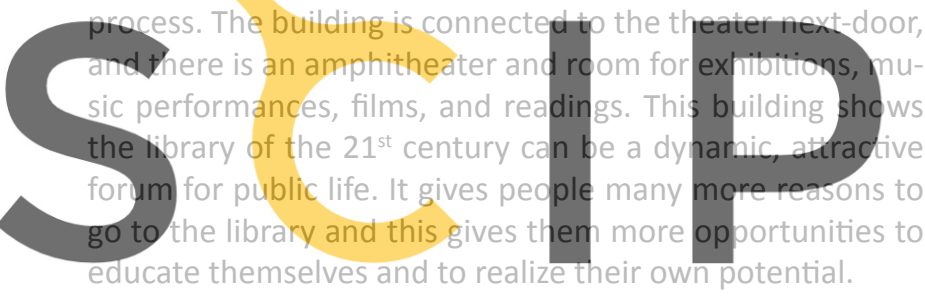

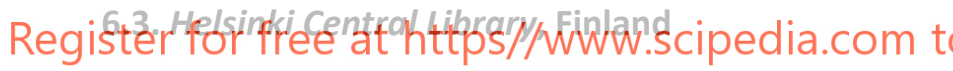

The new Central Library will be the main project of the year celebrating Finland's 100 years of independence in 2017. This symbolizes the strong status libraries enjoy in Finland even if the economic situation has affected libraries and their resources. The Central Library is planned to be in the Helsinki city center, opposite the Parliament, in close proximity to the new Music Hall, and near a major logistic hub where the main railway station, metro station, tram, and bus lines are all nearby. It will complement the culture cluster in the area with a house of literary art where literature can be expressed in new forms. Here too, the citizens have been involved in the planning and various experiments to test ideas. Many good ideas and much feedback were gathered from the people taking part in these events. People have also been asked to give ideas in participatory budgeting workshops; in these they are asked how they would spend 100,000 euros in developing new services. Four ideas are being developed further:

- an urban workshop, or makerspace, for the new digital culture;

- a new service for children and families which includes a fairy tale birthday party;

a borderless space for mind recreation including relaxing, silence, and serenity; and

Lost \& found, a new concept of fiction where classics are revived by current authors.

There are still 2,300 more ideas from the residents and partners to be considered. The vision of the Helsinki City Library for 2018 is "The library is a place full of new ideas. By sharing information, knowledge, and stories, we are creating a new civil society together".
Atideo of the new Central Library in Helsinki:
me-inside-the-helsinki-central-lib/ary
7. Conclusion

I will leave you with a quote by the American social refor-

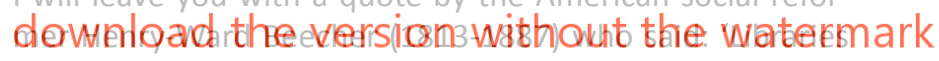
are not a luxury, they are one of the necessities of life'. Never were truer words spoken, and I believe they have more relevance today than ever before, particularly in the context of our discussions today and tomorrow.
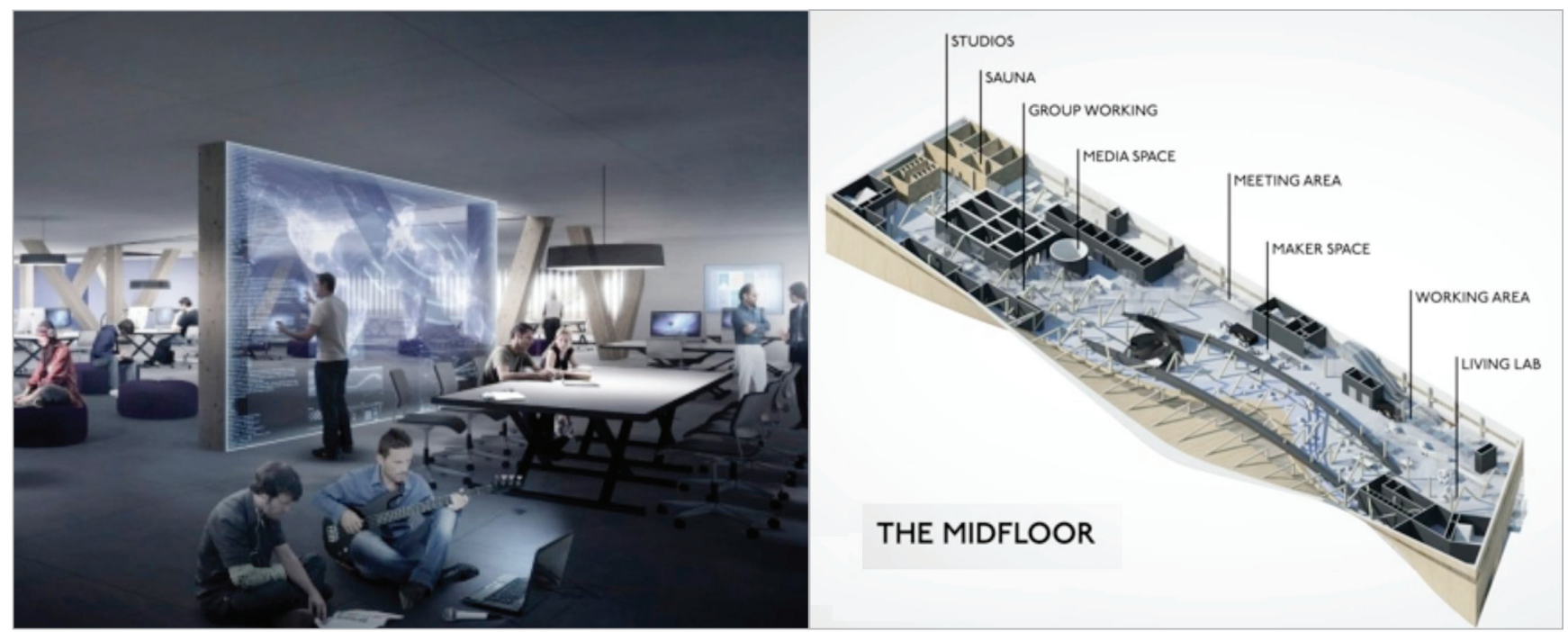

Future Helsinki Central Library, midfloor plan and internal view 


\section{Notes}

1. The North-South-South Higher Education Institution Network Programme opens up new opportunities for cooperation between higher education institutions (HEI) in Finland and in the developing countries. Centre for International Mobility (CIMO).

http://www.cimo.fi/services/publications/north-south-south

2. The World Café is a structured conversational process intended to facilitate open and intimate discussion, and link ideas within a larger group to access the "collective intelligence" or collective wisdom in the room.

http://en.wikipedia.org/wiki/World_Café_(conversational_ process)

\section{Bibliography}

Harju, Aaro (2003). Yhteisellä asialla - Kansalaistoiminta ja sen haasteet [Common Matters - Civic Activity and its Cha-

llenges]. Kansanvalistusseura, Vantaa.

Karhula, Päivikki (2012). "Strong libraries = strong societies: democratizing access to knowledge through libraries". Sig-

\section{num.}

http://www.odj.tsv.fi/index.php/signum/article/ download/6724/5466

Kranich, Nancy C. (2001). "Libraries, the internet, and de-
Lankes, R. David (2011). The atlas of new librarianship. Cambridge, MA: MIT Press, 408 pp. ISBN: 9780262015097

Lankes, R. David; Silverstein, Joanne; Nicholson, Scott (2007). "Participatory networks: the library as conversation". Information technology and libraries, v. 26, n. 4. http://ejournals.bc.edu/ojs/index.php/ital/article/ view $/ 3267$

http://dx.doi.org/10.6017/ital.v26i4.3267

Niegaard, Hellen; Lauridsen, Jens; Schulz, Knud (2009). Library space: inspiration for buildings and design. Danish Library Association.

http://www.librarybuildings.info/articles/inspirationbuilding-and-design

Schulz, Knud (2014). Transformation of Aarhus Main Library to Dokk1. Slide presentation, 106 slides. Munich, Nov. $4^{\text {th }}$. http://es.slideshare.net/KnudSchulz/munich-publ-librarynov-2014-transformation-from-main-to-dokk1-future-library https://www.aakb.dk/users/ksc

Sipilä, Sinikka (2013). "Strong libraries, strong societies". IFLA journal, v. 39 n. 1, p. 79.

http://ifl.sagepub.com/content/39/1/79.full http://dx.doi.org/10.1177/0340035213477061

Sipilä, Sinikka (2013). "The secret behind the success: Libraries in Finland"

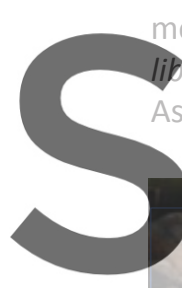

mocracy". In: Libraries \& democracy.

Nacy C. Kranich (ed.)

Association. ISBN: 083890808

$5^{2}$ Conieret
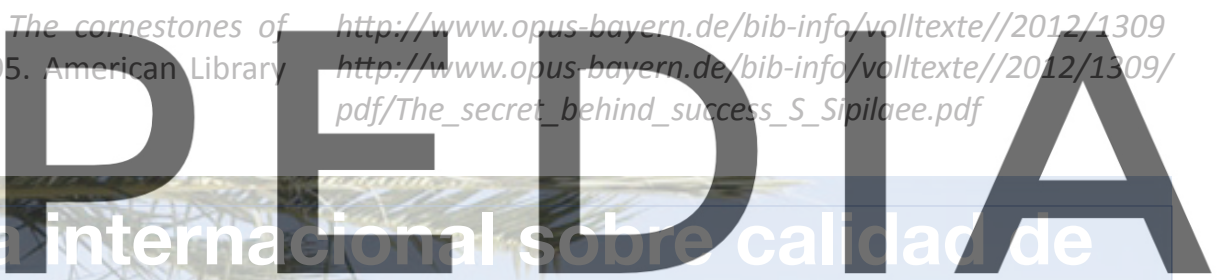

Register for free at https//www.scipedia.com to download the version without the watermark
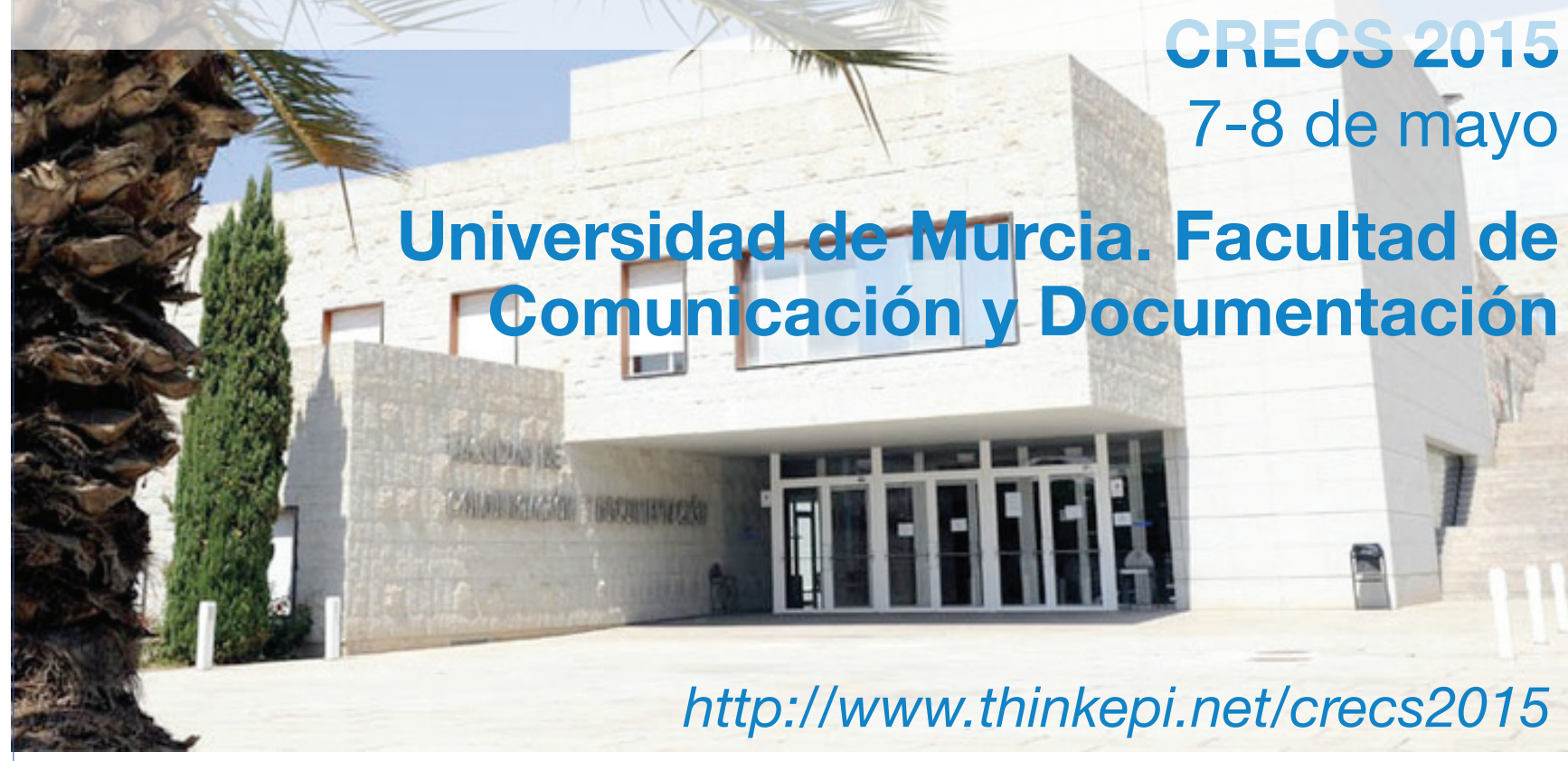

Universida

de-Murcia.

Facultad de Comuni cación y
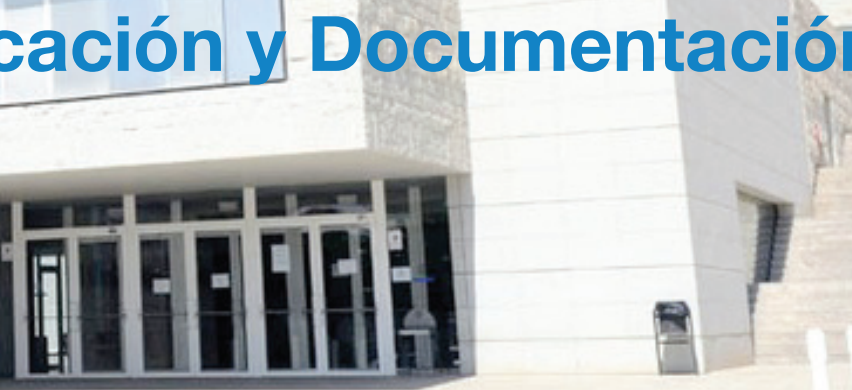

http://www. thinkepi.net/crecs2015
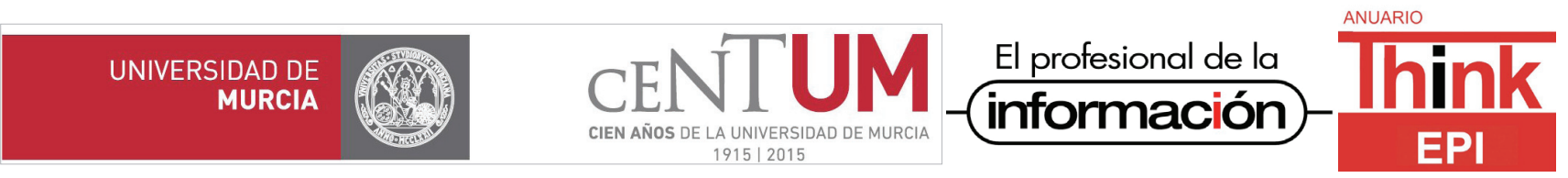


\section{Colección de libros de bolsillo El profesional de la información (Editorial UOC)}

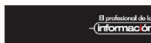 \\ @}

TECNOLOGÍAS DE LA WEB SEMÁNTICA JUANANTONIO PASTOR SÁNCHEZ

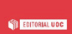

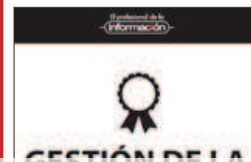

REPUTACIÓN ONLINE

DOCUMENTACIÓN AUDIOVISUA

EN TELEVISIÓN
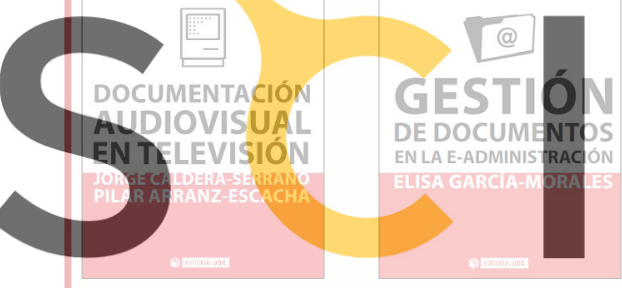

\section{IXI}

WIKIPEDIA

DE LA A A LA W

TOMÁS SAORIN
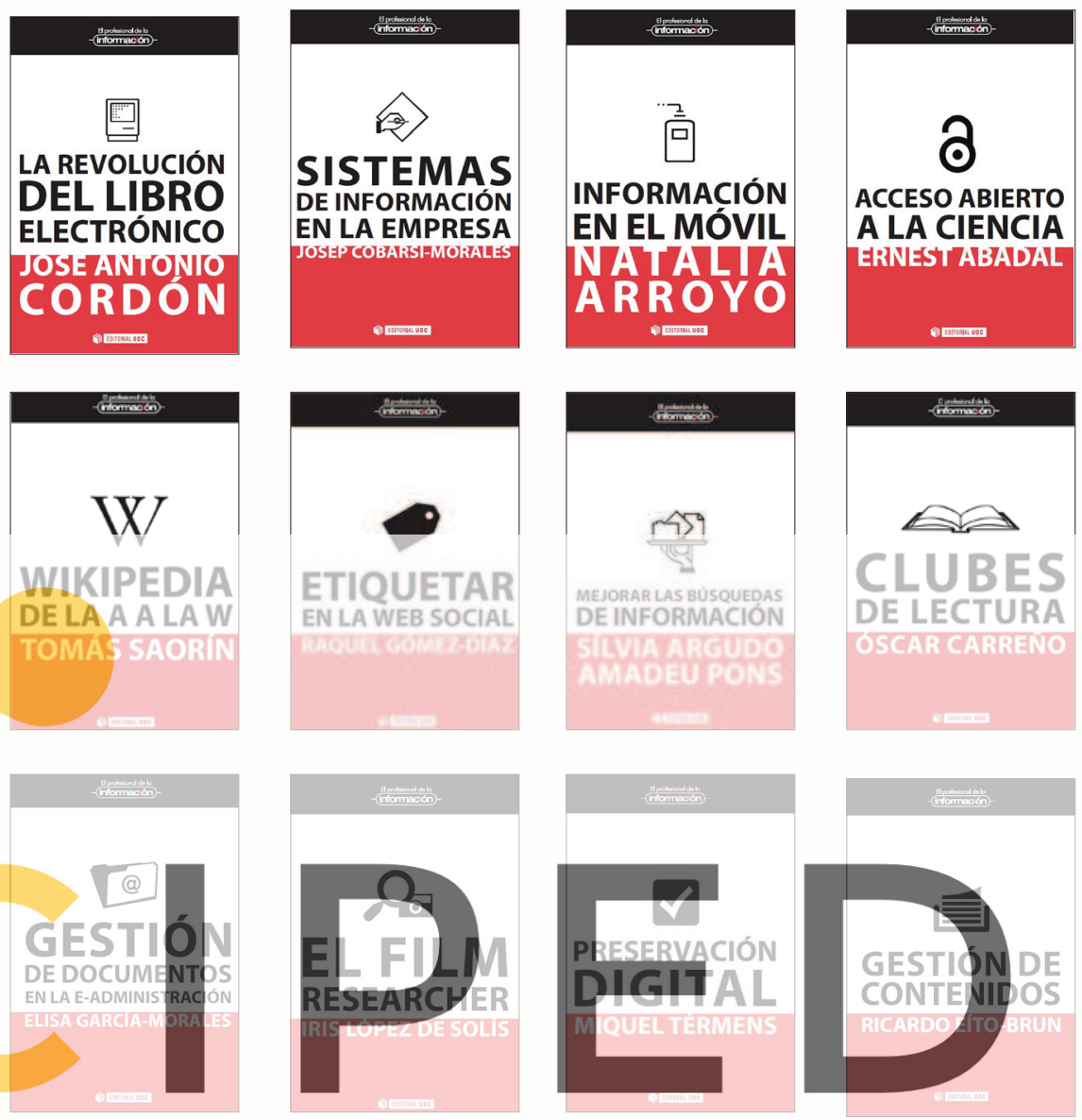

download the version without
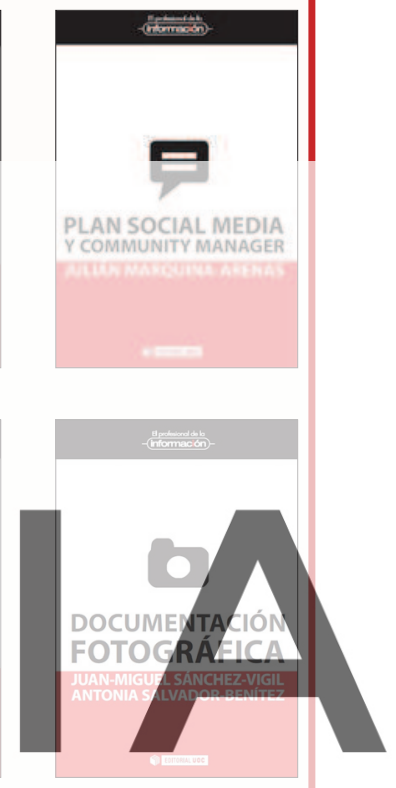

Register for free at https//www.scipedia.com to
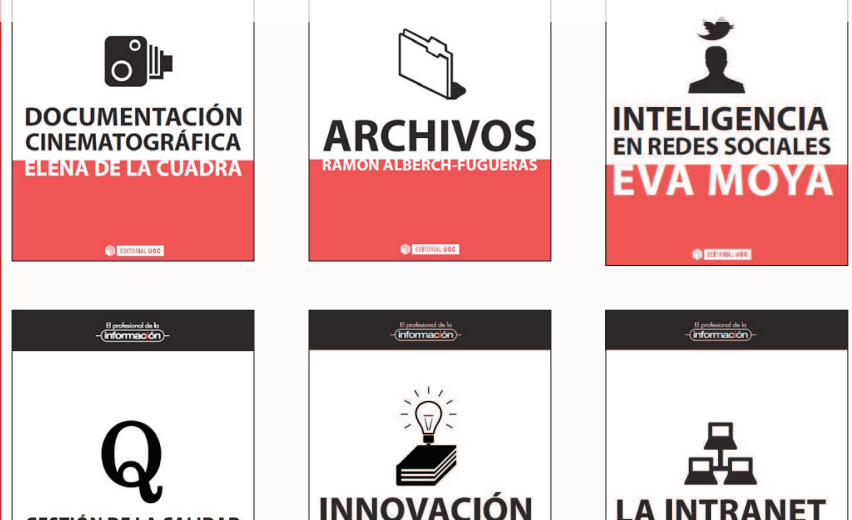

GESTIÓN DELACALIDAD EN LA BIBLIOTECA NURIABALAGUE .
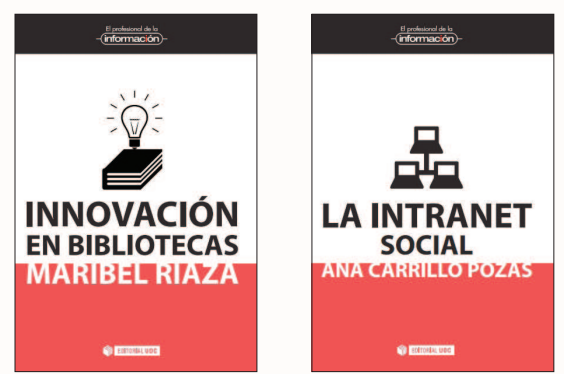

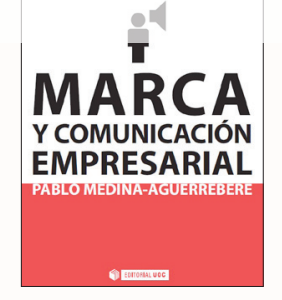

\section{EL CONTENT}

CURATOR

JAVIIER GUALEAR

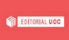
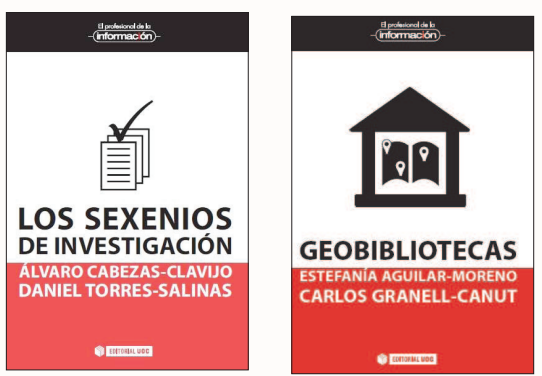

EDITORIAL UOG

Más información:

http://www.elprofesionaldelainformacion.com/libros.html 